\title{
Experimental study of mercury removal from exhaust gases
}

Fuel, 2014, 128, 451-457, doi: 10.1016/j.fuel.2014.03.041

\section{Magdalena Wdowin ${ }^{1 *}$, Malgorzata M. Wiatros-Motyka ${ }^{2}$, Rafal Panek ${ }^{3}$, Lee A. Stevens ${ }^{2}$, Wojciech Franus ${ }^{3}$, Colin E. Snape ${ }^{2}$}

\author{
${ }^{1}$ The Mineral and Energy Economy Research Institute of the Polish Academy of Sciences, \\ Wybickiego 7, 31-261 Kraków, Poland, e-mail: wdowin@meeri.pl, \\ ${ }^{2}$ Department of Chemical and Environmental Engineering, University of Nottingham, NG7 \\ 2RD Nottingham, United Kingdom,e-mails: enxmw2@nottingham.ac.uk, \\ Lee.Stevens@nottingham.ac.uk,Colin.Snape@nottingham.ac.uk \\ ${ }^{3}$ Department of Geotechnics, Civil Engineering and Architecture Faculty, Lublin University \\ of Technology, Nadbystrzycka 40, 20-618Lublin, Poland, e-mails: rapanek@gmail.com, \\ w.franus@pollub.pl \\ *Corresponding author; email: wdowin@meeri.pl Tel: +48 126171657.
}

\begin{abstract}
An initial study has been made of the use of synthetic zeolites for mercury capture from exhaust gases. Synthetic zeolites (Na-X and Na-P1), and for comparison a natural zeolite (clinoptilolite) and activated carbon with bromine $(\mathrm{AC} / \mathrm{Br})$ were tested for mercury uptake from a gaseous stream. The materials were subjected to mercury adsorption tests and their thermal stability was evaluated. The untreated synthetic zeolites had negligible mercury uptake, but after impregnation with silver, the adsorption of mercury was markedly improved. The synthetic zeolite Na-X impregnated with silver adsorbed significantly more mercury before breakthrough than the activated carbon impregnated with bromine, indicating the potential of zeolite derived from coal fly ash as a new sorbent for capture of mercury from flue gases.
\end{abstract}

Keywords: mercury capture, zeolites, fly ash 


\section{Introduction}

Removal of mercury $(\mathrm{Hg})$ from exhaust gases is becoming an increasingly important issue, especially in the context of a new United Nation's convention on reduction of mercury emissions and exposure on a global scale. Although mercury is released into the atmosphere from both natural and anthropogenic sources, fossil fuel burning (mainly coal combustion) is the second largest contributor [1]. During coal burning, mercury is released in its elemental form $\left(\mathrm{Hg}^{0}\right)$. However due to various thermo-chemical reactions occurring in the flue gas, some of it can be oxidised $\left(\mathrm{Hg}^{2+}\right)$ and/or be bonded to the particulate matter $\left(\mathrm{Hg}^{\mathrm{p}}\right)$ [2]. Oxidised (which is water soluble) and particle-bonded mercury can be captured by conventional air pollution control devices (APCD) such as fabric filters, cold and hot electrostatic precipitators (ESP), wet and dry flue gas desulphurization (FGD), and selective catalytic reduction (SCR). However, $\mathrm{Hg}^{0}$ (insoluble in water) is very difficult to capture by such systems [3]. As proportions of the emitted elemental, oxidised and particulate-bonded mercury vary within different coal plants, the performance of APCD as regards total capture of the mercury emitted also varies. To remove $100 \%$ of $\mathrm{Hg}$, the available control technologies must be combined with sorbents, which are able to oxidize and capture elemental mercury [4].

Many materials have been considered and studied for their potential to remove mercury from flue gases. These include activated carbons (impregnated with iodine, bromine and sulfur) and carbon - based materials such as fly ash, metals such as copper, lead, gold, silver) and their oxides and sulfides, calcium species (lime) and zeolites [5-12]. However most of these sorbents are less effective at higher temperature, have low capacities, cannot be regenerated and are easily deactivated by flue gas components such as sulfur oxides (SOx) [13-14], which means that the search for the ideal mercury sorbent is far from over [15]. Synthetic zeolites derived from coal fly ash have been suggested to be potentially 
economically feasible and environmentally friendly mercury sorbents, and can be considered to be worthy of further investigation.

It has been reported that the production of coal fly ash (CFA) is approximately 750 million tonnes per year, from which, on average, only $25 \%$ was utilised, the rest was disposed of as waste [16]. Although, the composition of CFA is complex and varies greatly [17], its utilisation has received a great deal of attention. Currently, fly ash is predominantly used as: a substitute material (e.g. as clinker) in the construction industry; a geotechnical material (e.g. asphalt filler, pavement base course) and soil stabiliser [16]. However, more interesting is its future possible application, as an adsorbent for various pollutants (including radioactive elements and heavy metals). It has been demonstrated that, manufacture of synthetic zeolites from CFA is a relatively straightforward procedure [18-22] and such materials have been found to be effective in the removal of various pollutants from different environments (water, soils, flue gases) [15, 23-29]. A comparison with natural zeolites shows that synthetic zeolites are better for the removal of mercury compounds, due to the consistent size of the channels and chambers, in contrast to the microstructure of natural zeolites sizes which can be variable and often associated with a number of lattice defects [30]. Moreover, successful regeneration of these materials has been reported $[15,31]$. Hence, the research into zeolitic materials and their potential for $\mathrm{Hg}$ removal can be justified with the aim of solving the problems of both utilisation of a waste material and removal of a toxic emission.

The main aim of the work described in this paper was to carry out a preliminary examination of the performance, suitability and potential of synthetic zeolites derived from fly ash to remove elemental mercury from flue gases. To improve their $\mathrm{Hg}$ adsorption efficiencies, the zeolitic materials were thermally activated and also loaded with silver (Ag), as evidence from previous work indicated that Ag may improve mercury removal rates [15]. 
In addition, for comparison natural zeolite - clinoptilolite (thermally activated and $\mathrm{Ag}$ impregnated) and activated carbon loaded with bromine ( $\mathrm{AC} / \mathrm{Br})$ were also tested for mercury uptake.

\section{Experimental}

\subsection{Sorbent preparation}

The synthetic zeolites have been synthesized in the hydrothermal reactions of fly ash, from hard coal combustion in Kozienice (Na-X) and Rybnik (Na-P1) Power Plants, Poland, with sodium hydroxide $(\mathrm{NaOH})$. The two types of zeolite Na-X, Na-P1 were prepared using the following conditions:

- Na-X: $20 \mathrm{~g}$ of fly ash was mixed with $0.5 \mathrm{dm}^{3}$ of $\mathrm{NaOH}$ at a concentration of 3 mol* $\mathrm{dm}^{-3}$ for 24 hours at $75^{\circ} \mathrm{C}$;

- Na-P1: $20 \mathrm{~g}$ of fly ash was mixed with $0.5 \mathrm{dm}^{3}$ of $\mathrm{NaOH}$ at a concentration of 3 mol* $\mathrm{dm}^{-3}$ for 24 hours at $95{ }^{\circ} \mathrm{C}$.

The preparation of the zeolites is on the quarter technical scale, and its repeatability has been confirmed in numerous experiments.

Prior to the $\mathrm{Hg}$ adsorption experiments, the samples were dried at $350{ }^{\circ} \mathrm{C}$ for 6 hours to remove moisture. In order to improve the zeolite's adsorption capacity towards $\mathrm{Hg}$, the synthetic zeolites were loaded with Ag using the ion exchange method. In addition, Na-P1 was also activated by melting with $\mathrm{AgNO}_{3}$. For comparison, a natural zeolite a clinoptilolite, Sokyrnytsya deposit, Ukraine was examined under the same experimental conditions as the synthetic materials.

\subsection{Morphology and textural characterisation}


The mineral composition of the synthetic zeolites was determined by means of powder X-ray diffraction (XRD) using a Philips X'pert APD diffractometer with the data being processed by Philips X'Pert and ClayLab ver. 1.0 software. Mineral phases were identified based on the PCPDFWIN ver. 1.30 database formalized by JCPDS-ICDD. The presence of zeolite phases analyzed in individual products were determined based on the characteristic dspacing, i.e. the Na-X $\left(\mathrm{d}_{\mathrm{hkl}}=14.47,3.81,5.73,8.85,4.42,7.54,4.81\right.$ and $\left.3.94 \AA\right)$, the Na-P1 $\left(\mathrm{d}_{\mathrm{hkl}}=7.10,5.01,4.10,3.18 \AA\right)$, and for clinoptilolite $\left(\mathrm{d}_{\mathrm{hkl}}=8.95,7.91,2.97,3.16,3.42,5.11\right.$, $4.65,3.97,3.96,3.95 \AA)$.

The morphology and chemical composition of the main mineral components of the zeolites were determined using an FEI Qanta 250 FEG scanning electron microscopy and energy dispersive spectroscopy (SEM/EDAX).

Textural properties of the zeolites, after degassing at $250{ }^{\circ} \mathrm{C}$ for $24 \mathrm{~h}$. under reduced pressure $\left(10^{-3} \mathrm{hPa}\right)$, were examined on an ASAP 2020 Micromeritics Analyzer. The specific surface area, pore volume as well as pore size distribution were determined by nitrogen adsorption/desorption isotherms at $-196.15^{\circ} \mathrm{C}$.

The specific surface area was determined based on the BET multilayer adsorption, where relative pressure $\left(\mathrm{p} / \mathrm{p}_{0}\right)$ was between 0.01 and 0.16 giving positive BET constants. The total pore volume $\left(\mathrm{V}_{\mathrm{p}}\right)$ was determined from the adsorbed nitrogen volume at $\mathrm{p} / \mathrm{p}_{0}=0.99$. Pore diameters $\left(D_{p}\right)$ were calculated according to $D_{p}=4 V_{p} / S_{\text {BET }}$. The distribution of pore volume $\left(\mathrm{R}_{\mathrm{p}}\right)$ was calculated by using a general isotherm equation based on $\mathrm{BJH}$ adsorption model at $\mathrm{p} / \mathrm{p}_{0}$ between 0.01 - 0.99 proposed by Barrett et al. [32] to calculate the percentage of micro, meso and macropore volumes respectively.

As investigated zeolites have different ion exchange capacities, their silver content was determined using inductively coupled plasma-mass spectrometry (ICP/MS) (Thermo-Fisher Scientific X-Series II). 


\subsection{Mercury adsorption tests}

The mercury adsorption tests were performed in the rig shown in Figure 1. The arrangement included: an elemental mercury generator in a water bath, a packed-bed Teflon tube reactor, containing $0.1 \mathrm{~g}$ of the sorbent, atomic fluorescence spectrometer (AFS) mercury detector (Millennium Merlin, PSA) and a data acquisition system. Mercury vapour was generated at $30{ }^{\circ} \mathrm{C}\left( \pm 0.5^{\circ} \mathrm{C}\right)$ and introduced at a known and constant concentration (e.g. $0.00288 \mathrm{mg}$ per $80 \mathrm{ml} / \mathrm{min}$ flow of $\mathrm{N}_{2}$ ) into an accurately controlled stream of carrier gas (initially - nitrogen). This gas mixture was passed through a Teflon tube $(0.47 \mathrm{~cm}$ id $)$ packed with a known mass $(0.1 \mathrm{~g})$ of the sorbent to be evaluated. The gas leaving the tube was diluted further with nitrogen before being presented to the atomic fluorescence detector. The detector output was logged over time in order to find the point at which breakthrough of mercury occurs. Some tests were extended to allow the determination of the equilibrium mercury content of the sorbents.

\subsection{Thermal stability of the sorbents}

The thermal stability of the materials was investigated using a TGA Q500 (TA Instruments) instrument and approximately $20 \mathrm{mg}$ of sorbent material. Analyses of spent materials provided evaluation of the quantity of $\mathrm{Hg}$ released, by monitoring the weight loss in the specified temperature range under a stream of inert gas. Samples were heated from ambient temperature to $110{ }^{\circ} \mathrm{C}$, and then maintained for 20 minutes at this temperature to remove moisture. Following this pre-treatment, the temperature was raised from 110 to $800{ }^{\circ} \mathrm{C}$ at a ramp rate of $20^{\circ} \mathrm{C} / \mathrm{min}$.

\subsection{Chemical state of captured mercury}


The chemical state of the mercury adsorbed on the zeolites was investigated by means of X-ray photoelectron spectroscopy (XPS). Samples were analysed using the Kratos AXIS ULTRA with a mono-chromated Al ka X-ray source (1486.6 eV) typically operated at 10 $\mathrm{mA}$ emission current and $12 \mathrm{kV}$ anode potential. The detector was used in FAT (fixed analyser transmission) mode, with pass energy of $80 \mathrm{eV}$ for wide scans and pass energy 20 $\mathrm{eV}$ for high resolution scans. In this study all of the spectra were calibrated to the binding energy of $\mathrm{C} 1 \mathrm{~s}$ photoelectrons at $284.6 \mathrm{eV}$. Analyses were performed under high vacuum (c.a. $10^{-10}$ Torr).

\section{Results and discussion}

\subsection{Mineralogical characteristic}

The zeolite materials, Na-X (a faujasite group), Na-P1 (a gismondite group) and clinoptilolite (a heulandite group) differ in internal structure, size of channels and chambers and chemical compositions. Mineralogical studies were carried out for zeolites thermally activated (i.e. dried at $350{ }^{\circ} \mathrm{C}$ ) and silver impregnated. The amount of pure zeolites (quantitative content from XRD analysis) varied from Na-X - $63 \%$, Na-P1 - $81 \%$ to clinoptilolite $-95 \%$.

SEM-EDS studies showed that in general the zeolites had different morphological forms: Na-X - being roughly of octahedral shape, Na-P1 - needlelike and clinoptilolite finely fibrous and plates-like. Ag was not visible as separate particles on zeolites surface, but for the Na-P1 sample loaded with Ag by melting the fine aggregates (from 0.3 to $1.0 \mu \mathrm{m}$ ) of Ag were observed on the surface of grains and the pores.

\subsection{Textural characteristic}


Table 1 shows the zeolite materials (thermal and Ag activated) have different textural properties, as described by the BET specific surface areas, which ranged between 11 (clinoptilolite/Ag) to $260 \mathrm{~m}^{2} / \mathrm{g}(\mathrm{Na}-\mathrm{X})$. The synthetic zeolites are mainly mesoporous, while clinoptilolite has higher macropore content. The pore size distribution analysis indicates that the tested zeolites have a mesoporous structure, where the proportion of mesopores is in the range of $42-61 \%$, with micropores ranging from 3 to $34 \%$. Na-X zeolites have a greater proportion of pores in the micropore range $(31-34 \%)$ than the other zeolites resulting in specific surface areas greater than $200 \mathrm{~m}^{2} / \mathrm{g}$. However, the lowest percentage was recorded for the Na-P1, Na-P1/Ag and Na-P1/Ag/Melt $(\sim 3 \%)$. All the materials had a relatively high proportion of macropores $(12-55 \%)$, with the natural zeolite, clinoptilite, having the highest macropore content $(\sim 55 \%)$, and lowest specific surface area $\left(19 \mathrm{~m}^{2} / \mathrm{g}\right.$ - untreated, $14 \mathrm{~m}^{2} / \mathrm{g}$ Ag loaded). All Ag loaded samples show a reduction in total pore volume from untreated zeolites, indicating that $\mathrm{Ag}$ is blocking or filling some of the pores.

All the adsorption isotherms showed a characteristic hysteresis loop which is associated with capillary condensation taking place in mesopores. However, the shape of the hysteresis loops are represented by III/IV type of isotherms according to the IUPAC classification indicating the presence of "bottle shape" pores.

The silver content of the tested materials varied from 6.9 for clinoptiloite to $37.4 \mathrm{w} / \mathrm{w} \%$ for Na-P1/Melt/Ag (see Table 2). Na-P1/Melt/Ag has the highest silver content, but, interestingly, Na-X/Ag had less than Na-P1/Ag despite having higher ion exchange capacity (Na-X $-1.8 \mathrm{meq} / \mathrm{g}, \mathrm{Na}-\mathrm{P} 1-0.72 \mathrm{meq} / \mathrm{g})$. The quoted values are the average of 2 runs, but it should be noted that a very high dilution factor $(100,000)$ had to be applied during the analyses with a consequent influence on the accuracy attained in the silver determination.

\subsection{Mercury adsorption tests}


The data from the mercury adsorption tests are presented in Table 3. All tests were repeated 2 - 3 times and the presented breakthrough mercury uptakes at the breakthrough (5 and $10 \%)$ are average values.

Initially, tests were carried out with $80 \mathrm{ml} / \mathrm{min}$ flow of $\mathrm{N}_{2}$. However due to the high adsorption capacity of $\mathrm{Na}-\mathrm{X} / \mathrm{Ag}$ the pseudo equilibrium could not be reached even after 10 days under these conditions (see Figure 2), and consequently the flow was doubled to 160 $\mathrm{ml} / \mathrm{min}$ of $\mathrm{N}_{2}$ for this sample.

The zeolitic materials (thermally treated at $350{ }^{\circ} \mathrm{C}$ ), were unable to remove more than 10 wt $\%$ of mercury, and their capacities at the breakthrough could not be correctly calculated. For the untreated zeolites tests were terminated after 1 hour, due to the low uptake efficiency.

As Table 3 shows the addition of Ag to the tested samples dramatically improved the performance of the zeolites to mercury capture, with $\mathrm{Na}-\mathrm{X} / \mathrm{Ag}$ achieving the greatest $\mathrm{Hg}$ uptakes corresponding to the highest BET surface area and the highest combined micro and meso pore volumes (see Table 1). This data implies that both micro and meso pores are important for mercury capture, and multilayer adsorption is an important parameter, but only to a certain point, as seen from Na-P1/Ag with greater combined meso and macro pore volume and Ag loading but lower mercury uptake. In a comparison with the activated carbon loaded with bromine, the silver loaded $\mathrm{Na}-\mathrm{X}$ zeolite achieved an approximately four times greater $\mathrm{Hg}$ uptake (for $10 \%$ breakthrough).

Although, Na-P1 loaded with silver via melting technique achieved slightly better mercury breakthrough rates than Na-P1 impregnated via ion exchange, it was not able to withstand the higher flow rate $(160 \mathrm{ml} / \mathrm{min})$ of flue gas, hence the melting procedure is considered a less effective method of impregnation for this sorbent. As expected from the 
literature review [25] clinoptilolite $\mathrm{Hg}$ uptake was negligible, especially in comparison to the fly ash derived materials.

As expected from the previous work [33-35] the initial X-ray photoelectron spectroscopy (XPS) analyses indicated that mercury formed an amalgam in the silver loaded zeolites. In contrast, no $\mathrm{Hg}$ was identified in untreated zeolites, which is most likely due to the fact that all mercury adsorbed on untreated zeolites was in its elemental form, and when the high vacuum was applied during XPS analyses, mercury was desorbed from the samples. Such process was also described by Samaz et al. [36] who investigated mercury adsorption onto brominated activated carbons.

Examples of breakthrough curves of for the best performing zeolithic material (Na$\mathrm{X} / \mathrm{Ag}$ ) and $\mathrm{AC} / \mathrm{Br}$ are presented in Figure 2. For these materials initial kinetic studies were carried out.

By plotting the mercury uptake versus time for $\mathrm{Na}-\mathrm{X} / \mathrm{Ag}$ and $\mathrm{AC} / \mathrm{Br}$ it can be seen that the uptake for both adsorbents is initially linear with time (Figure 3). However the treated activated carbon is only linear up to approximately 3000 minutes adsorption time, which corresponds to its $10 \mathrm{wt} \%$ breakthrough. The linear uptakes indicate that initially the reaction for both sorbents has zero order kinetics and can be described by the following equation.

$$
Q=k^{*} t
$$

Where $Q$ is that quantity adsorbed, $k$ the rate constant and $t$ time, respectively. Here, the rate of reaction is independent of concentration, but proportional to time. $\mathrm{Hg}$ is said to be in excess of the adsorbent, and increasing the concentration will have zero effect on the rate of reaction. Rate constants of both materials are shown in Table 4.

The data suggests that initially $\mathrm{Na}-\mathrm{X} / \mathrm{Ag}$ has identical rate constants $\left(\mathrm{K}_{1}\right)$ with $\mathrm{AC} / \mathrm{Br}$ and therefore has similar rate of adsorption towards mercury. However, the $\mathrm{AC} / \mathrm{Br}$ adsorbent shows a reduced reaction rate beyond 3000 minutes indicating slower kinetics with $10 \%$ 
breakthrough. Na-X/Ag continues to adsorb $\mathrm{Hg}$ linearly up to 15000 minutes with no change in rate of adsorption.

\subsection{Thermal Gravimetric Analysis}

As showed in Figure 4 all tested materials exhibited an initial weight change at $100-110$ ${ }^{\circ} \mathrm{C}$, which is contributed to loss of free bonded moisture. That was followed by the gradual weight loss of 1 - 2 wt $\%$ up to c.a. $260{ }^{\circ} \mathrm{C}$ for all the samples, which suggests that the most of the adsorbed $\mathrm{Hg}$ was retained as non-volatile compound. As successful regeneration of silver impregnated zeolites was reported at around $400{ }^{\circ} \mathrm{C}$ [31], it was expected that the majority of the adsorbed mercury will be released at this temperature. However, data from the TGA analyses showed that the weight loss of all materials between 260 and $800{ }^{\circ} \mathrm{C}$ do not correspond to the mercury uptake during the adsorption tests (uptake at the $10 \%$ breakthrough, for the materials tested in $80 \mathrm{ml} / \mathrm{min}$ flow rate - as seen in Table 3). For example, by comparing fresh and spent $\mathrm{Na}-\mathrm{X} / \mathrm{Ag}$ thermographs it can be seen that after initial weight loss at around 110 - spent material lost only 4.8 wt $\%$ of its mass at $400{ }^{\circ} \mathrm{C}$, while the fresh $\mathrm{Na}-\mathrm{X} / \mathrm{Ag}$ lost around 1.8 wt $\%$ suggesting that only c.a. $3 \%$ of weight loss was contributed to the mercury release (c.a. 38 wt $\%$ mercury was adsorbed onto this material). While the fresh Na-P1/Ag at the same temperature range $\left(110-400{ }^{\circ} \mathrm{C}\right)$ lost 2.7 wt $\%$ while spent material lost - 5 wt \% suggesting that c.a. $2 \%$ weight loss was contributed to the mercury desorption (c.a. 4.9 wt \% of mercury was adsorbed). These findings indicate that it is possible that different gas than nitrogen is needed to regenerate silver impregnated zeolite, what seems to be supported by the other work - Dong et al. [37] reported regeneration in argon, while Weekman et al. - in methane [38]. Future work will aim to fully investigate zeolites regeneration potential along with the impact of gasification and combustion flue gas components on the sorbents mercury adsorption and its thermal stability. 


\section{Conclusion}

Synthetic zeolites derived from fly ash appear to be a promising material for $\mathrm{Hg}$ removal from exhaust gases. Hydrothermal syntheses of fly ash with $\mathrm{NaOH}$ water solution at different conditions (temperature and time of reaction) give various structural and morphological forms of zeolites. Depending on the conditions of synthesis faujasite or gismondite type of zeolites were obtained. A comparison with a natural zeolite (clinoptilolite) has showed that the synthetic zeolites have superior textural properties for $\mathrm{Hg}$ adsorption.

Untreated synthetic zeolites have negligible $\mathrm{Hg}$ uptakes; however silver impregnation improves their efficiencies greatly. Ag loading achieved by ion exchange was superior then that achieved by melting method. The highest breakthroughs uptakes were achieved by Na$\mathrm{X} / \mathrm{Ag}$, corresponding to the highest BET surface area and highest combined micro and meso porosity of the tested zeolites, suggesting multilayer adsorption is important for mercury capture. $\mathrm{Na}-\mathrm{X} / \mathrm{Ag}$ has similar rate of adsorption toward mercury to that of the alternative AC/Br sample, but achieved c.a. 4 times higher breakthrough capacity. Mercury remained bound to the sorbent until c.a. $260{ }^{\circ} \mathrm{C}$, and partially desorbed at the temperature at approximately $400{ }^{\circ} \mathrm{C}$, indicating excellent thermal stability and the possibility of regeneration of the synthetic zeolite. Although the presented data are preliminary and the experiments were carried out only in a nitrogen atmosphere, the obtained results, especially in a comparison with commercially activated carbon, confirm the clear potential of the synthetic zeolite loaded with silver as a new possible mercury sorbent. Future work will include testing of $\mathrm{Na}-\mathrm{X} / \mathrm{Ag}$ in both gasification and combustion atmospheres, and investigations of their regeneration potential, which will allow assessing its suitability to be applied in real industrial conditions. 


\section{Acknowledgements}

The authors would like to acknowledge the financial support of RCND Applied Research Program PBS1/A2/7/2012.

\section{References}

[1] UNEP, 2013, Mercury Time to act, http://content.yudu.com/A20ki2/MercuryTimetoAct/resources/index.htm. Accessed online on 01.06.2013.

[2] Wang SX, Zhang L, Li GH, Wu Y, Hao JM, Pirrone N et al. Mercury emission and speciation of coal-fired power plants in China. Atmos Chem Phys 2010; 10: 1183-1192.

[3] Yang H., Xu Z., Fan M., Bland A.E., Judkins R. R., (2007) - Adsorbents for capturing mercury in coal-fired boiler flue gas. J Hazard Mater. 146(1-2):1-11.

[4] Presto AA, Granite EJ. Survey of catalysts for oxidation of mercury in flue gas. Environ Sci Technol 2006; 40 (18): 5601-5609.

[5] Granite EJ, Pennline HW, Hargis RA. Novel sorbents for mercury removal from flue gas. Ind Eng Chem Res 2000; 39: 1020-1029.

[6] Lopez-Anton MA, Tascon JMD, Martinez-Tarazona MR. Retention of mercury in activated carbons in coal combustion and gasification flue gases. Fuel Process Technol 2002; 77-78: 353-358.

[7] Wu J, Cao Y, Pan W, Shen M, Ren J. Evaluation of mercury sorbents in a lab-scale multiphase flow reactor, a pilot-scale slipstream reactor and full-scale power plant. Chem Eng Sci 2008; 63: 782 - 790.

[8] Dunham GE, De Wall RA, Senior CL. Fixed-bed studies of the interaction between mercury and coal combustion fly ash. Fuel Process Technol 2003; 82: 197-213. 
[9] Presto AA, Granite EJ. Survey of catalysts for oxidation of mercury in flue gas. Environ Sci Tech 2006; 40 (18); 5601-5609.

[10] Baltrus J, Granite E, Pennline H, Stanko D, Hamilton H, Rowsell L et al. Surface characterization of palladium-alumina sorbents for high-temperature capture of mercury and arsenic from fuel gas. Fuel 2009; 89: 6, 1323-1325.

[11] Fuente-Cuesta A, Diaz-Somoano M, Lopez-Anton MA, Cieplik M, Fierro JLG, Martínez-Tarazona MR. Biomass gasification chars for mercury capture from a simulated flue gas of coal combustion. J Environ Manage 2012; 98: 23-28.

[12] Wiatros-Motyka MM, Sun Ch-g., Stevens LA, Snape CE. High capacity co-precipitated manganese oxides sorbents for oxidative 4 mercury capture, Fuel 2013; 109: 559-562.

[13] Couling DJ, Nguyen HV, Green WH. Screening of metal oxides and metal sulfides as sorbents for elemental mercury at elevated temperatures. Fuel 2012; 97: 783-795.

[14] Presto AA, Granite EJ. Impact of sulphur oxides on mercury capture by activated carbon. Environ Sci Tech 2007; 41: 6579-6584.

[15] Liu Y, Bisson TM, Yang H, Xu Z. Recent developments in novel sorbents for flue gas clean up Fuel Process Technol 2010; 91: 1175-1197.

[16] Blissett RS, Rowson NA. A review of the multi-component utilisation of coal fly ash. Fuel 2012; 97: 1-23.

[17] Vassilev SV, Vassileva CG. Methods for characterization of composition of fly ashes from coal-fired power stations: a critical overview. Energy Fuels 2005; 19(3): 1084-98.

[18] Querol X, Moreno N, Umaña JC, Juan R, Hernández S, Fernandez-Pereira C, et al. Application of zeolitic material synthesized from fly ash to the decontamination of waste water and flue gas. J Chem Technol Biotechnol 2002; 77: 292-298.

[19] Adamczyk Z, Białecka B. Hydrothermal synthesis of zeolites from Polish coal fly ash. Pol J Environ Stud 2005; 14(6): 713-719. 
[20] Gross-Lorgouilloux M, Caullet P, Soulard M, Patarin J, Moleiro E, Saude I. Conversion of coal fly ashes into faujasite under soft temperature and pressure conditions. Mechanisms of crystallisation. Microporous Mesoporous Mater 2010; 131: 407-417

[21] Franus W. Characterization of X-type Zeolite Prepared from Coal Fly Ash. Pol J Environ Stud 2012; 21(2): 337-343.

[22] Izidoro JC, Alves FD, FS, Wang S. Characteristics of Brazilian coal fly ashes and their synthesized zeolites. Fuel Process Technol 2012; 97: 38-44.

[23] Shevade S, Ford RG. Use of synthetic zeolites for arsenate removal from pollutant water Water Res 2004; 38(14-15): 3197-204.

[24] Arenillas A, Smith KM, Drage TC, Snape CE. $\mathrm{CO}_{2}$ capture using some fly ash-derived carbon materials. Fuel 2005; 84: 2204-2210.

[25] Moutsatsou A, Stamatakis E, Hatzitzotzia K, Protonotarios V. The utilization of Ca-rich and $\mathrm{Ca}-\mathrm{Si}$-rich fly ashes in zeolites production. Fuel 2006; 85: 657-663.

[26] Franus W, Wdowin M. Removal of ammonium ions by selected natural and synthetic zeolites. Gosp Sur Min-Miner Res Manag 2010; 26(4): 133-148.

[27] Misalides P. Application of natural zeolites in environmental remediation: A short review Microporous Mesoporous Mater 2011; 144: 15-18.

[28] Wdowin M, Franus W, Panek R. Preliminary results of usage possibilities of Carbonate and zeolitic sorbents in $\mathrm{CO}_{2}$ capture. Fresenius Environ Bull 2012; 21(12): 3726-3734.

[29] Chałupnik S, Franus W, Wysocka M, Gzyl G. Application of zeolites for radium removal from mine water. Environ Sci Pollut Res 2013 DOI 10.1007/s11356-013-1877-5.

[30] Morency JR, Panagiotou T, Senior CL. Zeolite sorbent that effectively removes mercury from flue gases. Filtr Sep 2002; 39(7): 24-26. 
[31] Liu Y, Kelly DJA, Yang H, Lin CCH, Kuznicki SM, Xu Z. Novel regenerable sorbent for mercury capture from flue gases of coal-fired power plant. Environ Sci Technol 2008; 42: 6205-6210.

[32] Barrett EP, Joyner LG, Halenda PP. The determination of pore volume and area distributions in porous substances. I. Computations from nitrogen isotherms. J Am Chem Soc $1951 ; 73: 373-380$.

[33] Yan, T.Y. A novel process for Hg removal from gases. Ind Eng Chem Res 1994; 33, 3010-3014.

[34] Nowakowski, R., Kobiela, T., Wolfram, Z., Duś, R. Atomic force microscopy of Au/Hg alloy formation on thin Au films. Appl Surf Sci 1997; 115, 217-231.

[35] Long, S.J., Scott, D.R., Thompson, R.J. Atomic absorption determination of elemental mercury collected from ambient air on silver wool, Anal Chem 1973; 45, 2227-2233.

[36] Sasmaz, E., Kirchofer, A., Jew, A.D., Saha, A., Abram, D., Jaramillo, T.F. et al. Mercury chemistry on brominated activated carbon. Fuel 2012; 99, 188-196.

[37] Dong, J., Xu, Z., Kuznicki, S.M. Mercury removal from flue gases by novel regenerable magnetic nanocomposite sorbents, Environ. Sci. Technol. 2009; 43, 3266-3271.

[38] Weekman, W.V. and Yan, T.Y. Regenerative mercury removal process Patent: http://www.patents.com/us-5419884.html. 
Table 1 Textural parameters of tested zeolitic materials

\begin{tabular}{|c|c|c|c|c|c|c|}
\hline Sorbent & $\begin{array}{l}\text { BET surface } \\
\text { area }\left(\mathbf{m}^{2} / \mathbf{g}\right)\end{array}$ & $\begin{array}{c}\mathbf{D}_{\mathbf{p}}(\mathbf{4 V} / \mathbf{A}) \\
(\mathbf{n m})\end{array}$ & $\begin{array}{c}V_{\mathbf{p}} \\
\left(\mathrm{cm}^{3} / \mathrm{g}\right)\end{array}$ & $\begin{array}{c}\mathbf{R}_{\mathbf{p}} \\
\text { micropores } \\
{[\%]}\end{array}$ & $\begin{array}{c}\mathbf{R}_{\mathbf{p}} \\
\text { mesopores } \\
{[\%]}\end{array}$ & $\begin{array}{c}\mathbf{R}_{\mathbf{p}} \\
\text { macropores } \\
{[\%]}\end{array}$ \\
\hline $\mathrm{Na}-\mathrm{X}$ & 260 & 8.29 & 0.22 & 31.46 & 55.58 & 12.96 \\
\hline $\mathrm{Na}-\mathrm{X} / \mathrm{Ag}$ & 203 & 11.50 & 0.16 & 34.42 & 50.00 & 15.58 \\
\hline Na-P1 & 88 & 21.08 & 0.34 & 2.76 & 61.81 & 35.43 \\
\hline Na-P1/Ag & 53 & 22.51 & 0.21 & 2.97 & 67.29 & 29.73 \\
\hline Na-P1/Ag/Melt & 65 & 20.59 & 0.26 & 2.87 & 61.95 & 35.18 \\
\hline Clinoptilolite & 19 & 24.30 & 0.06 & 6.40 & 43.00 & 50.60 \\
\hline Clinoptilolite/Ag & 14 & 43.08 & 0.04 & 11.30 & 33.95 & 54.75 \\
\hline $\mathrm{AC} / \mathrm{Br}$ & 1015 & 2.60 & 0.45 & 70.40 & 28.9 & 0.60 \\
\hline
\end{tabular}

Table 2 Silver contents in zeolites (results from ICP/MS)

\begin{tabular}{ccc}
\hline Sorbent & Ag in solid form (w/w \%) & Ag \\
& 24.1 & 2.24 \\
Na-X/Ag & 37.4 & 3.47 \\
Na-P1/Melt/Ag & 36.7 & 3.4 \\
Na-P1/Ag & 6.9 & 0.64 \\
Clinoptilolite/Ag & & \\
\hline
\end{tabular}

Table 3 Untreated and Ag loaded zeolites performances towards $\mathrm{Hg}$ capture

\begin{tabular}{|c|c|c|c|c|c|c|}
\hline Sorbent & $\begin{array}{c}\text { Flow } \\
\text { rate } \\
\mathrm{ml} / \mathrm{min}\end{array}$ & $\begin{array}{c}\text { Evaporation } \\
\text { rate } \\
(\mathrm{mg} / \mathrm{min})\end{array}$ & $\begin{array}{l}\text { Time to } \\
\text { break- } \\
\text { through } \\
(5 \%)^{*}, \\
\text { min }\end{array}$ & $\begin{array}{c}\text { Break- } \\
\text { through } \\
\text { capacity } \\
(5 \%) * \\
\text { w/w \% }\end{array}$ & $\begin{array}{c}\text { Time to } \\
\text { break- } \\
\text { through } \\
(10 \%)^{* *} \\
\text { min }\end{array}$ & $\begin{array}{c}\text { Break- } \\
\text { through } \\
\text { capacity } \\
(10 \%) * * \text {, } \\
\text { w/w \% }\end{array}$ \\
\hline $\mathrm{Na}-\mathrm{X}$ & 80 & 0.00288 & 2 & 0.0058 & ND & ND \\
\hline $\mathrm{Na}-\mathrm{X} / \mathrm{Ag}$ & 80 & 0.00288 & 13017 & 37.46 & 13431 & 38.32 \\
\hline $\mathrm{Na}-\mathrm{X} / \mathrm{Ag}$ & 160 & 0.005766 & 5327 & 30.34 & 5461 & 31.16 \\
\hline $\mathrm{Na}-\mathrm{P} 1$ & 80 & 0.00286 & ND & ND & ND & ND \\
\hline $\mathrm{Na}-\mathrm{P} 1 / \mathrm{Ag}$ & 80 & 0.002883 & 1536 & 4.35 & 1723 & 4.93 \\
\hline $\mathrm{Na}-\mathrm{P} 1 / \mathrm{Ag}$ & 160 & 0.005766 & 365 & 2.09 & 400 & 2.28 \\
\hline Na-P1/Ag/ Melt & 80 & 0.002883 & 1992 & 5.7 & 2174 & 6.2 \\
\hline Clinoptilolite & 80 & 0.00286 & 2 & 0.006 & ND & ND \\
\hline Clinoptilolite/Ag & 80 & 0.00286 & 5 & 0.014 & 6 & 0.017 \\
\hline $\mathrm{AC} / \mathrm{Br}$ & 80 & 0.002883 & 2538 & 7.3 & 2910 & 8.2 \\
\hline
\end{tabular}

Table 4 The quantity adsorbed Q, rate constant $\mathrm{k}$ and $\mathrm{R}^{2}$ for adsorbents $\mathrm{AC} / \mathrm{Br}$ and $\mathrm{Na}-\mathrm{X} / \mathrm{Ag}$

\begin{tabular}{ccccccc}
\hline Sorbent & $\mathbf{Q}_{\mathfrak{t}} / \mathbf{m g}$ & $\mathbf{K}_{\mathbf{1}} \mathbf{~ m g} / \mathbf{m i n}$ & $\mathbf{R}^{\mathbf{2}}$ & $\mathbf{Q}_{\mathbf{m}} / \mathbf{m g}$ & $\mathbf{k}_{\mathbf{2}} \mathbf{m g} \mathbf{m i n}$ & $\mathbf{R}_{\mathbf{2}} \mathbf{2}$ \\
\hline $\mathrm{AC} / \mathrm{Br}$ & 7.96 & 0.0028 & 0.9997 & 12.89 & 0.0016 & 0.9801 \\
$\mathrm{Na}-\mathrm{X} / \mathrm{Ag}$ & 8.03 & 0.0028 & 0.9999 & 40.43 & - & - \\
\hline
\end{tabular}

$\mathrm{Q}_{\mathrm{t}}$ denotes quantity of $\mathrm{Hg}$ adsorbed at 3000 minutes, $\mathrm{Q}_{\mathrm{m}}$ maximum uptake, $\mathrm{k}_{1}$ is the rate constant up to 3000 minutes, and $\mathrm{k}_{2}$ from 3000 to 7000 minutes 


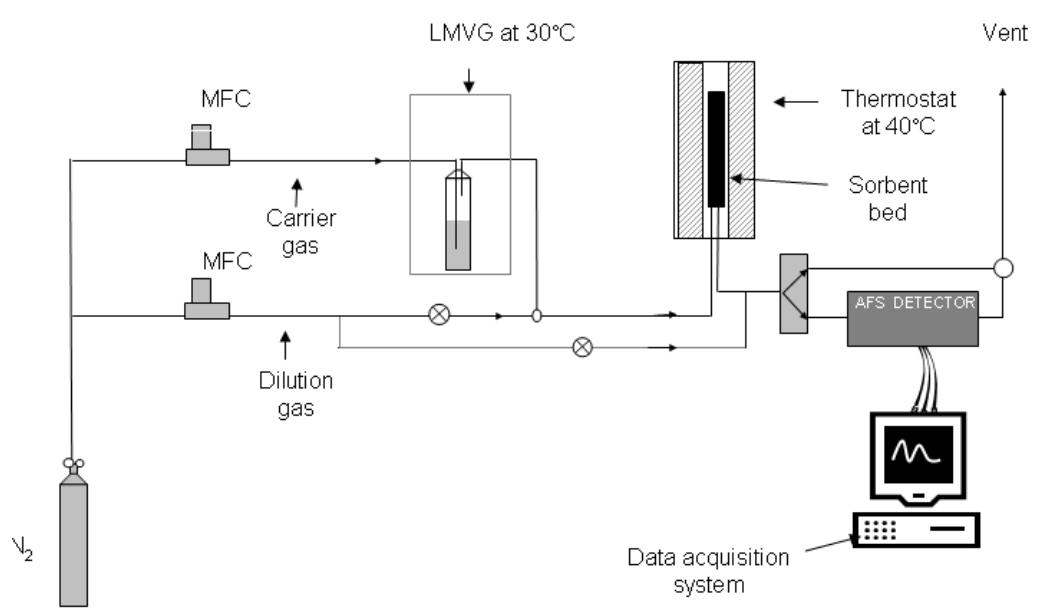

Fig. 1. Schematic of $\mathrm{Hg}$ adsorption rig

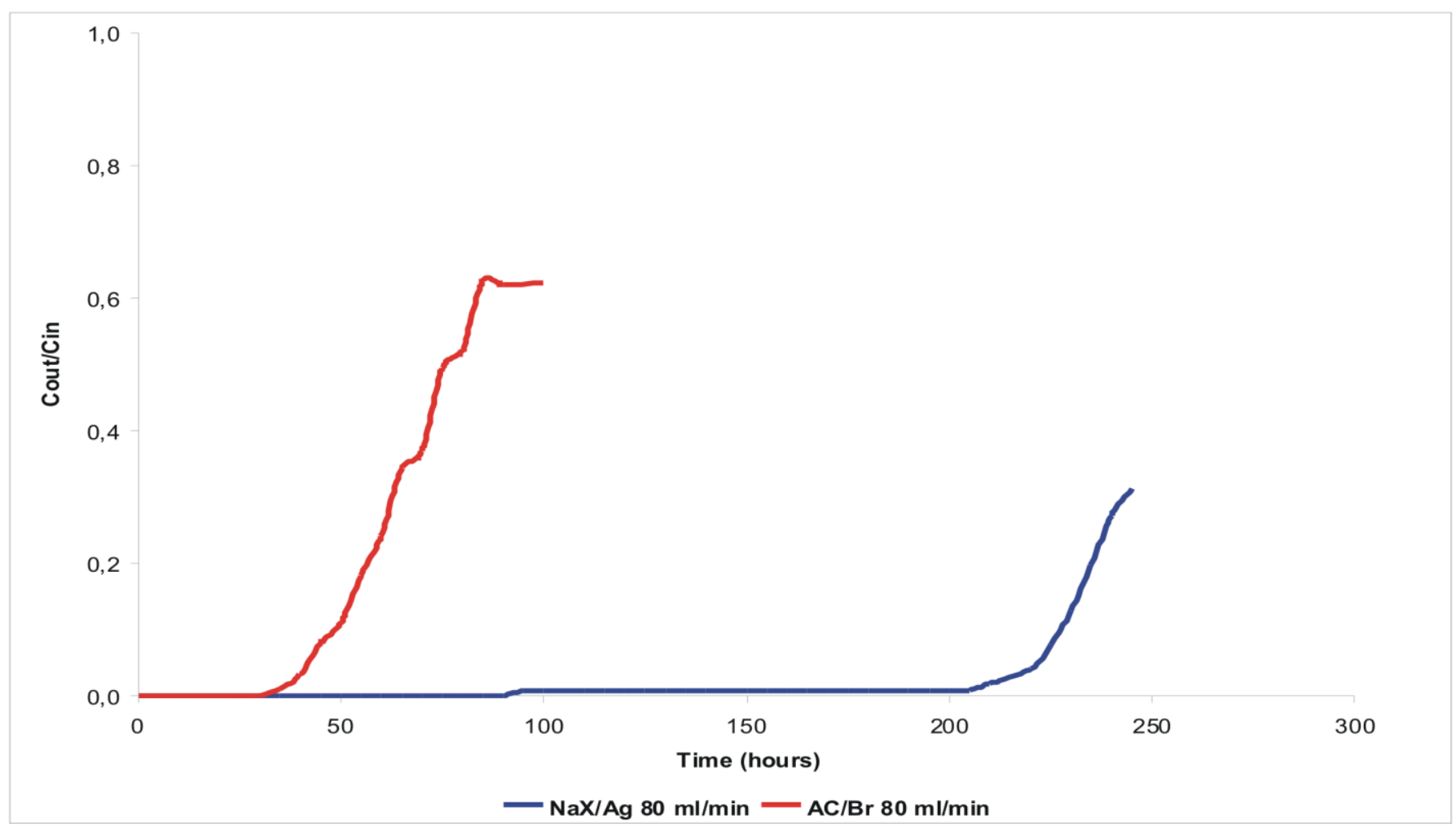

Fig. 2.

Fig. 2. The breakthrough curves for $\mathrm{NaX} / \mathrm{Ag}$ and $\mathrm{AC} / \mathrm{Br}$ 


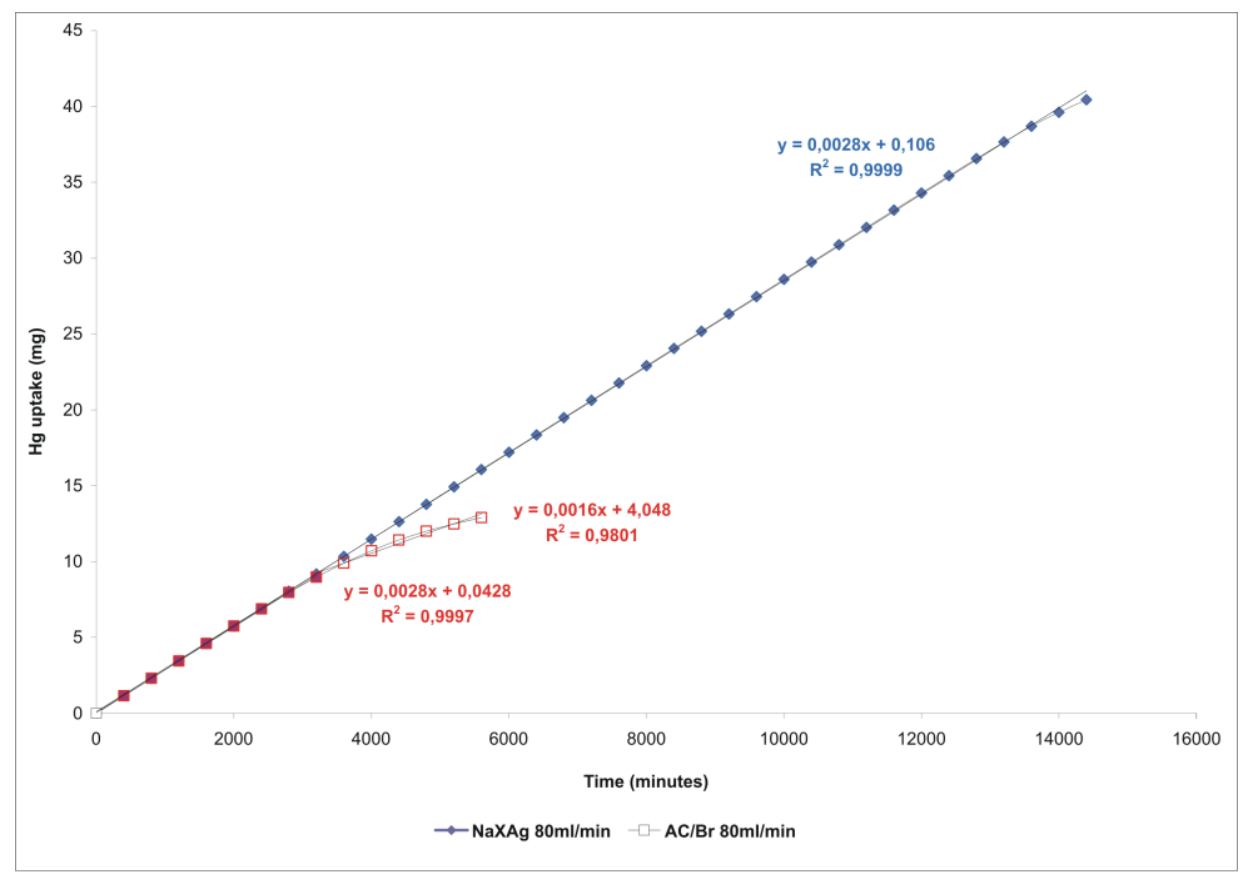

Fig.3.

Fig. 3. Mercury uptake for $\mathrm{Na}-\mathrm{X} / \mathrm{Ag}$ and $\mathrm{AC} / \mathrm{Br}$ adsorbents

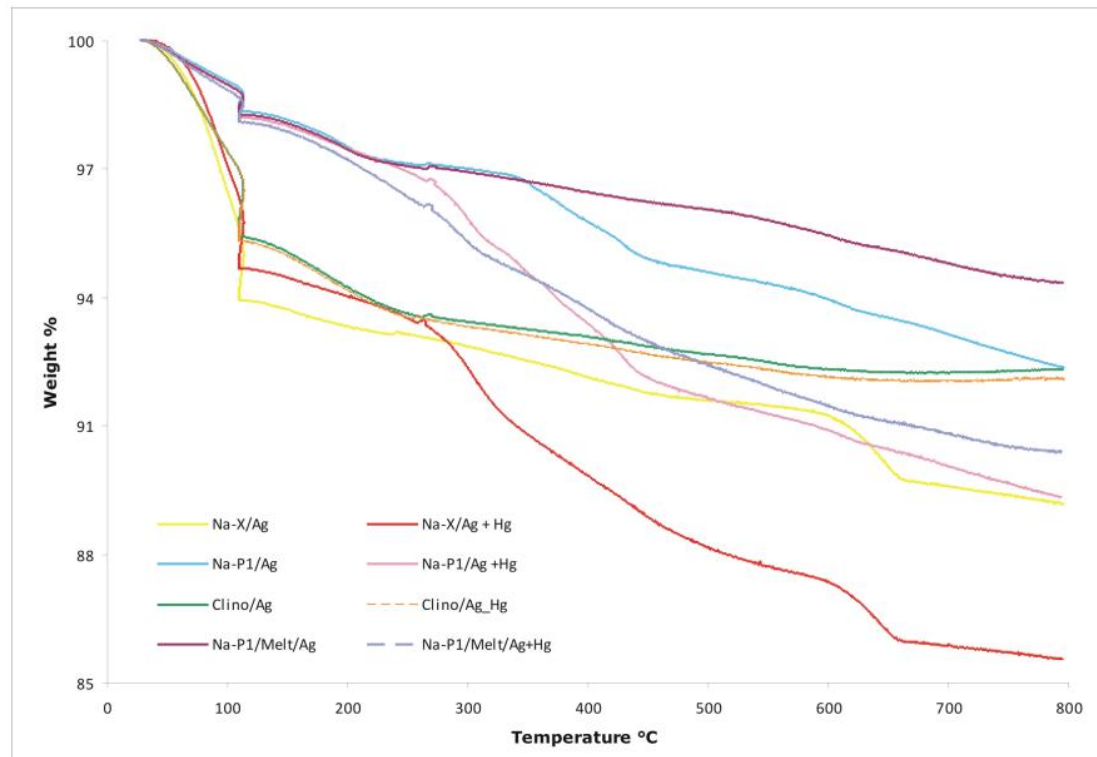

Fig.4.

Fig. 4. TGA plots of tested zeolitic materials 